\title{
Tawau-Polloc Port Cross Border Special Economic Zone As A Development Path For Bangsamoro Autonomous Region
}

\author{
Abdul Rahim Anuar, Laila Suriya Ahmad Apandi and Rusdi Omar \\ School of International StudiesUniversiti Utara Malaysia, Sintok, Kedah, Malaysia
}

Correspondence Author: Abdul Rahim Anuar, School of International StudiesUniversiti Utara Malaysia, Sintok, Kedah,Malaysia. E-mail: abd182@uum.edu.my

Received date: 23 April 2018, Accepted date: 1 July 2018, Online date: 30 July 2018

Copyright: (c) 2018 Abdul Rahim Anuar et al. This is an open-access article distributed under the terms of the Creative Commons Attribution License, which permits unrestricted use, distribution, and reproduction in any medium, provided the original author and source are credited.

\begin{abstract}
This research analyzed the feasibility of the Tawau-Polloc Port Cross-Border Special Economic Zone (CBSEZ) under the three-tier regional development corridor framework, which consists of the Greater Sulu Sulawesi Economic Corridor, Southern Mindanao Economic Growth Corridor, and Bangsamoro Development Corridor. The establishment of the Tawau-Polloc Port CBSEZ will integrate the economic regions of Sabah and Bangsamoro Autonomous Region through bilateral trade and investment. The formation of this zone is supported by the respective economic fundamentals and factor endowment between the two regions that complement one another. The implementation of Tawau-Polloc Port CBSEZ will further strengthen the barter trade relationship that has existed for centuries between Tawau and the islands of Tawi-Tawi, Sulu, and Basilan. Tawau-Polloc Port CBSEZ needs to be implemented in stages and in line with the Bangsamoro Development Plan (2014-2019). Tawau-Tawi-Tawi Special Economic Zone is the first initiative in establishing the CBSEZ and it will be extended to Tawau-Sulu, Tawau-Basilan, and eventually to Tawau-Polloc Port. However, there exists a shadow economy in the barter trade relationships between Tawau and Tawi-Tawi, Sulu, and Basilan. This could become a barrier to the implementation of the CBSEZ. Therefore, the laws and regulations under the CBSEZ need to be formulated clearly and transparently to overcome the challenges associated with the shadow economy. An efficient and transparent trade-investment administration would guarantee the success of the Tawau-Polloc Port CBSEZ and have an economic spillover effect on the economy of Bangsamoro and Sabah..
\end{abstract}

Key words: Tawau Bangsamoro Autonomous Region Cross-Border Special Economic Zone Tawi-Tawi

\section{INTRODUCTION}

In 1989, the Government of Philippines (GPH) and the Moro Islamic Liberation Front (MILF) freedom fighters had reached a peace agreement with the formation of the Autonomous Region in Muslim Mindanao (ARMM) under the decree of Republic Act (no. 6734), thus bringing to an end the decade-long conflict. Malaysia was also involved in the peace process between GPH and MILF since 2001 by playing the role of a peace facilitator and contributed toward the establishment of the Bangsamoro Autonomous Region (BAR) in 2014. BAR replaced ARMM under the Comprehensive Agreement on Bangsamoro (CAB) in 2014.

Prior to this, GPH and MILF also accepted Malaysia as the head of the International Monitoring Team (IMT) in 2004. The IMT headquarters is located in Cotabato City and it also includes other countries, namely Brunei, Indonesia, Japan, Norway, and the European Union. The IMT's main objective is to monitor the implementation of the peace process between GPH and MILF. Since its inception, IMT has been successful in reducing terrorist-related incidence and conflicts between armed factions in Mindanao [1].

Figure 1 shows that BAR is composed of five provinces, namely Lanao del Sur and Maguindanao on the mainland, and the island provinces of Basilan, Sulu, and Tawi-Tawi, which are often referred to as "BASULTA".

Under the CAB, Bangsamoro Development Authority (BDA) was established for planning the economic development of the Bangsamoro. In relation to this, BAR has launched the Bangsamoro Development Plan (BDP) with the aim of developing the regional economy and thus improve the socio-economic welfare of its residents in a stable and peaceful political environment. This factor can potentially become an attraction to foreign investors, including Malaysia and Sabah, to invest in the BAR region. BAR is the poorest and most underdeveloped region in the Philippines because of the skirmishes and battles between GPH and Islamic freedom fighters throughout the region.

The BDP is a six (6) year development plan with two phases covering 2014-2019. Phase I-the Transitional Development Plan-lays the direction for existing and planned quick impact interventions by the Government and development partners through to the middle of 2016 . This will ensure a smooth transition from the current ARMM to the Bangsamoro Transition Commission, and eventually, to the Bangsamoro Transition Authority. The Medium Term Development Plan (2016-2019), meanwhile, focuses on strategic interventions and investments that promote inclusive growth to ensure security, stability, and job creation [2].

Thus, the objective of this research is to investigate the feasibility of establishing the Tawau-Polloc cross-border special economic zone (CBSEZ) with the view to promote economic development in the BAR region. 


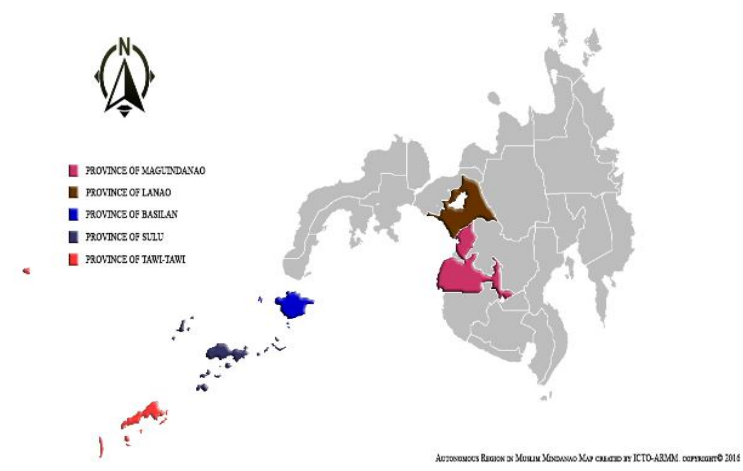

Fig. 1: Bangsamoro Autonomous Region Source: https://armm.gov.ph/discover-armm/map/

\section{Literature Review:}

The explanation of the cross-border economic integration shall be based on the concept of regional economic integration (REI) that was introduced by Viner [3]. REI is agreements between countries to reduce and subsequently eliminate tariff and non-tariff barriers to promote the free flow of goods and services as well as production factors (such as labour) of member countries that set up an integrated economic region. An REI can take the form of a free trade area [4].

A wider economic market integration would bring about an economic condition that is more dynamic in the long term through the increase in trade volume, investment, and economic welfare amongst the member countries that form the economic integration region.

Studies in Asian cross-border economies have been examined previously by Asian Development Bank which investigated the Greater Mekong Subregion (GMS) [5]. The GMS region involved the cross-border economies of six countries, namely Cambodia, China (Yunan and Guangxi Zhuang counties), Laos, Myanmar, Thailand, and Vietnam.

There were also researchers who studied cross-border economy between Thailand with its neighbouring countries (Malaysia, Myanmar, Laos and Cambodia) [6,8] and Malaysia-Indonesia borders [9-11]. All these studies evaluated the cross-border integration potential of Thailand with the countries in the effort of developing rural border regions. All above-mentioned studies discussed the development potential of neighbouring border townships in generating regional economic growth in areas that are relatively under-developed. They believe CBEZ could have a spillover effect on the border region economies.

\section{Methodology:}

This research adopted a qualitative approach by employing questionnaires, conducting interviews, and gathering secondary data from the region under study. A survey was performed in February 2017 involving the residents of Cotabato. The research sample was 300 respondents that covered the urban (100 respondents), semi-urban (100 respondents), and rural (100 respondents) areas. The areas involved include (i) Barangay Malanguit, (ii) Upper D'Lag, (iii) Barangay Kudal, (iv) Barangay Tapudok, (v) Poblacion Supermarket Site, and (vi) Bagua.

The respondent selection was performed randomly in each of the locations selected for this study. A structured questionnaire was used to collect data related to the respondent profile, which included the following items: ethnicity, religion, education, income and expenses, owned assets, and perceptions on regional economic development, politics, and social issues. A Likert scale from 1 (very low priority/strongly disagree/not a problem) to 5 (very high priority/strongly agree/very big problem) was used to measure respondent perception on politics, regional economic development, and issues related to non-traditional security (NTS) threats.

To simplify the analysis, respondent's perceptions are classified into two main categories, which were disagreed (Likert Scale 1,2$)$ and agree $(3,4,5)$ for questions related to politics. These same categories were also applied for questions related to economic development, which were a low and high priority Meanwhile, responses to questions related to issues of NTS threats were categorised under not a problem and problem.

Interviews were also performed with representatives from Sabah BIMP-EAGA Traders Association (BETA) and several barter traders in Tawau. These interviews were conducted in November 2017. The objective of the interviews was to further investigate the feasibility of establishing a Tawau-Polloc Port CrossBorder Special Economic Zone.

\section{RESULTS AND DISCUSSION}

\section{Malaysia's Role as Peace Facilitator:}

Figure 2 shows that $85 \%$ of the total respondents agreed with the role played by Malaysia as a facilitator that is qualified, effective, and skilled. However, about $60 \%$ of respondents did not agree with the intervention by Malaysia as a peace facilitator because of the issues surrounding Sabah that is claimed by GPH on Malaysia. This means that the involvement by Malaysia as a peace facilitator is specifically for resolving the political and armed conflict between GPH and MILF.

\section{Local Demand for Development:}

Figure 3 illustrates that $89 \%$ of the total respondents indicated that development is needed in the area under study. They are in dire need of reliable electricity supply and access to clean and hygienic water $(90 \%)$, followed by infrastructure and amenities upgrading, poverty eradication programmes, and job opportunities.

\section{NTS Threat:}

Figure 4 shows the NTS threat issues faced by the respondents under study. The main problems faced by them include poverty, lack of job opportunities, and corruption. Other problems include drug trafficking, crime, private army conflict, and feudal conflict, all which has captured less attention than the critical problems in the area under study.

The results of the study were consistent with the economic environment in BAR. The poverty incidence of its residents increased from 47\% (in 2006) to 54\% (in 2015), with the number of residents who are classed as poor increasing from 1.5 million people to almost 2 million people for the period 2006-2015 [12].

The poverty rate and the number of poverty-stricken residents in BAR are amongst the highest when compared to other regions in the Philippines. In terms of employment, the labour force participation rate in BAR was 48\% in 2017 (April), which is the lowest amongst the regions in the Philippines, and way below the national average $(61 \%)[13]$.

\section{Barter Trade Intensity:}

The research results from the interviews with the BETA representatives highlighted that trading and investment are amongst the crucial factors for the development of BAR, particularly in the BASULTA region, as well as Tawau and Sandakan in the east coast of Sabah. This is mainly due to the fact that there is a strong barter trade relationships between Sabah (Tawau and Sandakan) with BASULTA.

Table 1 shows that barter trade intensity between Tawau and BASULTA. On the average, the total Tawau-BASULTA trade was RM25 million per year for the duration 2005-2014. From the perspective of trade balance, barter trade favours Tawau (Sabah) more.

Traders from BASULTA purchase the basic necessities - rice, sugar, and cooking oil—from Sabah and then sell them in the local market. Meanwhile traders from Tawau and Sandakan import marine products. This shows the comparative advantage between Sabah and BASULTA to be complementary. 


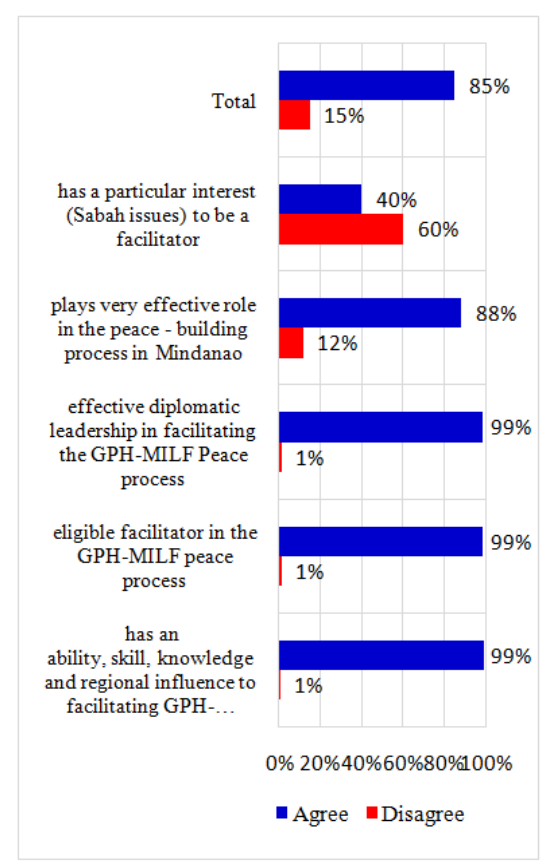

Fig. 2: Respondent perception on the role by Malaysia as a peace facilitator.

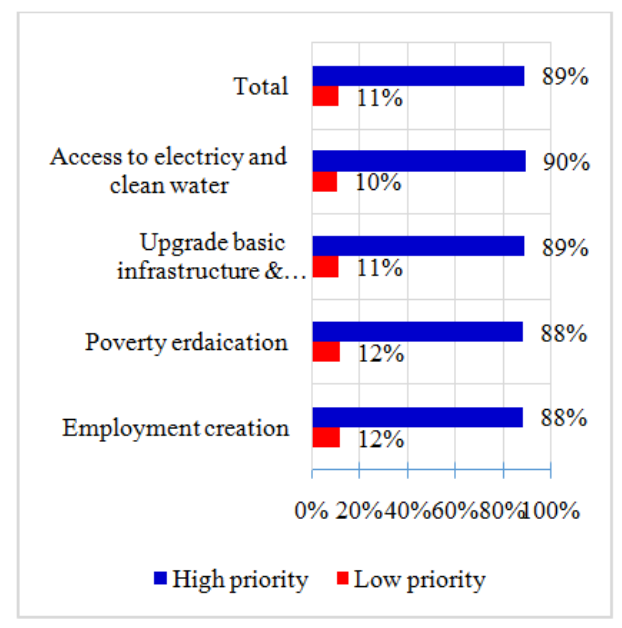

Fig. 3: Respondent perception regarding need and priority for development in the area under study.

Table 1 reflects the importance of barter trade to Tawau and BASULTA traders. In fact, both sides complained that their income was affected when the Sabah government-imposed trade sanctions between Sabah and the Philippines from April 2016. This sanction had to be imposed because of the increasing frequency of incidents involving piracy and kidnapping in the eastern waters of Sabah that had jeopardized the security and safety of Sabah [14].

However, The BETA representatives believed there exists a highly informal sector in barter trade. Such informal economy has had a negative effect on BASULTA, of which include[15]:

- $\quad$ the structural weakness of state institutions and formal sector explain the resilience of informal economy in the Bangsamoro,

- $\quad$ the informal economy provides livelihood opportunities to marginalized and poor communities, and

- $\quad$ shadow economies sustain the power and authority of local strongmen, political elites, and clans.

In summary, the findings showed that trade and investment are among the key factors that can develop the backward BAR economy as well as promote the Tawau economy. Malaysia, in addition to performing its role as a peace facilitator and leading the IMT, needs to upgrade its role as an investor by providing financial capital that is sorely needed for the development of the BAR region. Currently, Japan International Cooperation Agency (JICA) is the major investor in Mindanao, including BAR, actively involved in economic and social development projects [16].

Tawau-Polloc Port Cross-Border Special Economic Zone:

The recommendation for forming the Tawau-Polloc Cross-Border Special Economic Zone (CBSEZ) in the BAR region shall involve the three-tier regional development corridors, namely Greater Sulu Sulawesi Economic Corridor, Southern Mindanao Economic Growth Corridor, and Bangsamoro Development Corridor. Figure 5 shows the concept of economic integration in the Bangsamoro region with Sabah, based on the three-tier development corridor.

\section{Tawi-Tawi Special Economic Zone:}

The Philippines Economic Zone Authority (PESA) and Regional Economic Zone (REZA) in BAR had identified BASULTA, Polloc Port (Parang, Maguindanao), Marawi City, and Malabang (Lanao Del Sur) as free economic zone (FEZ) [17]. Specifically, in Tawi-Tawi, PanglimaSugala has been identified as a special economic zone that was approved by REZA in May 2017 [18]. 


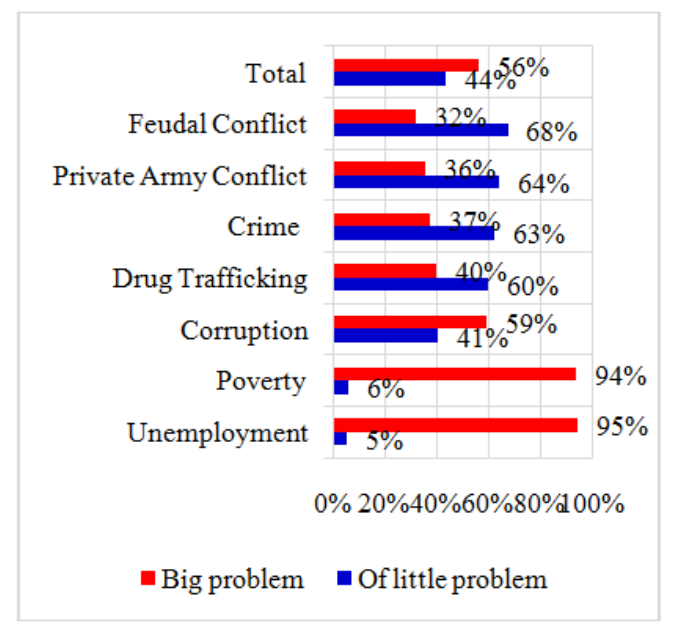

Fig. 4: Respondent perception regarding the non-traditional security threats.

Table 1: Barter trade between Tawau and BASULTA (RM'000).

\begin{tabular}{|l|l|l|l|l|}
\hline Year & Import & Export & 13,133 & Total Trade \\
\hline 2005 & 770 & 13,676 & 13,903 & \\
\hline 2010 & 555 & 13,413 & 14,231 & 12,363 \\
\hline 2011 & 48 & 11,063 & 13,461 & 13,121 \\
\hline 2012 & 20,421 & 12,605 & 31,484 & 13,365 \\
\hline 2013 & 618 & 25,854 & 13,223 & \\
\hline 2014 & 45 & $9,358)$ & 25,899 \\
\hline
\end{tabular}

Source: Royal Malaysian Customs Department, Tawau

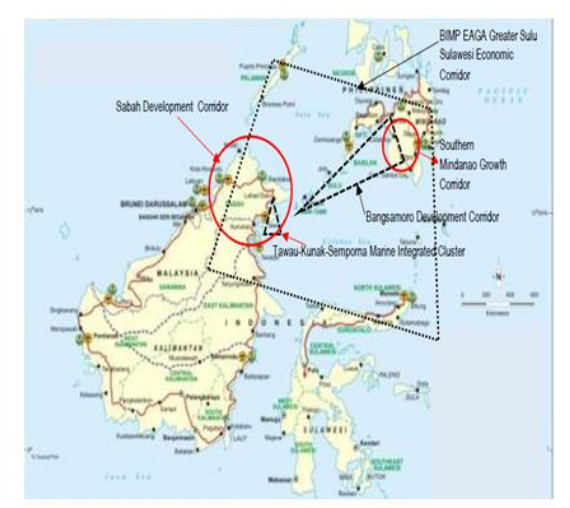

Fig. 5: BIMP EAGA, Sabah, and Mindanao Development Corridor .

Figure 6 illustrates the barter trade relationship between Tawau-Sandakan with the islands of BASULTA. Industries in the Tawi-Tawi FEZ focussed on agricultural, fishing, and agar-agar farming sectors. Meanwhile, for Tawau FEZ, its industries are concentrated on processing factories, agriculture, and fisheries.Thus, Tawai-Tawi has a comparative advantage in the agriculture and maritime industry. Tawau has a comparative advantage in the agricultural and maritime product processing industries. This increases the inter-barter trade relationship between the two regions. Tawau will be the centre for processing agricultural and maritime products and export platform to the Borneo market, including Brunei, and Peninsular Malaysia.

Conclusion:

Tawau-Polloc Port CBSEZ can be implemented as an economic development platform in the BAR region in general, and specifically in BASULTA with the establishment of the Tawau-Tawi-Tawi CBSEZ as the first initiative. The CBSEZ can attract other ASEAN investment into the region. The laws and regulations related to the CBSEZ need to be transparent to facilitate trade and investment amongst the traders and investors with the local authorities, as well as to overcome the problems associated with the shadow economy or informal sector in the barter trade relationship between Sabah and BAR.

Economic development in BAR, however, needs to be supported by border security in the BASULTA islands, Sulu and the Celebes Sea by the Malaysian, Philippine and Indonesian governments. The Abu Sayyaf Group (ASG) is a threat in the Sulu and Celebes Seas. Though small-scale and locally-oriented, the ASG is prolific, and targets fishing vessels for lucrative kidnap-for-ransom operations. In 2016, ASG coordinated a number of ship hijackings and kidnappings, taking hostage not only Indonesian and Malaysian fishermen, but also several westerners. Indonesia, Malaysia and the Philippines launched the INDOMALPHI Trilateral Cooperative Arrangement (TCA). The stated goal is to address "the security challenges associated with each country's border waters". The initiative is showing promise as a first step towards improving the security architecture in an area where terrorist activity has had major economic impact [19] 


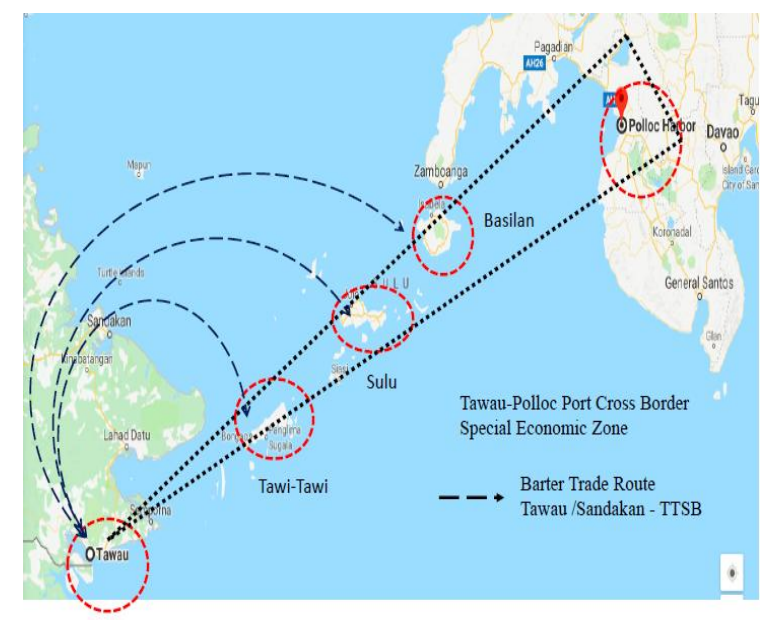

Fig. 6: Tawau-Polloc Port Cross-Border Special Economic Zone and Barter Trade Route between Tawau/Sandakan and BASULTA.

\section{REFERENCES}

[1] Abdul Rahim Anuar, 2015. Rubrik Pembangunan Pekan Sempadan Malaysia-Kalimantan: Tawau-Pulau Nunukan. Journal of Borneo Social Transformation Studies, 1(1).

[2] Asian Development Bank, 1998. Economic Cooperation In The Greater Mekong Subregion: An Overview. Manila: Asian Development Bank.

[3] Bangsamoro Development Agency, 2014. Bangsamoro Development Plan 2014-2019. Retrieved from bangsamoro development.org/Bangsamorodevelopment-plan.

[4] Choen, K., 2008. Cross-Border Trade And Commerce In Thailand: Policy Implications For Establishing Special Border Economic Zones (Unpublished doctoral thesis). Asian Institute of Technology, Bangkok, Thailand.

[5] Dendy, K., 2009. Strategi engembangan Wilayah PerbatasanAntar Negara: Memacu Pertumbuhan Ekonomi Entikong Kabupaten Sanggau Provinsi Kalimantan Barat (Tesis magister yang tidakditerbitkan). UniversitasDiponegoro, Indonesia.

[6] International Monitoring Team, 2017. IMT's roles in Mindanao. Briefing notes presented on February 10, 2017 at IMT Headquarters, Cotabato City.

[7] Julia, C., 2016. Barter Trade Ban Will Devastate Sabah Economy, Says Local Businessman. Retrieved from http://www.themalaymailonline.com/.

[8] Japanese International Cooperation Agency, 2017. Mindanao peace and development assistance by Japan. Briefing notes presented on February 10, 2017 at IMT Headquarters, Cotabato City.

[9] Julmuniri, J., 2017. P129-M Polloc Port Investment To Boost Mindanao Economic Corridor. Retrieved from http://www.manilatimes.net/

[10]Lord, M. and P. Tangtrongita, 2014. Special Border Economic Zone in the Indonesia-Malaysia-Thailand Growth Triangle (IMT-GT). MPRA Paper No. 61060.

[11]Maneepong, C. and C.T. Wu, 2004. Comparative Borderland Development in Thailand. ASEAN Economic Bulletin, 21(3), 133-166.

[12]Macleod, A., 2017. Under The Radar: Security In The Sulu Sea Is Set To Improve. Retrieved fromhttps://globalriskinsights.com/2017/10/can-sulu-seabecome-secure-new-initiative/.

[13]Philippines Statistics Authority, 2017. Employment Situation in April 2017 (Final Results). Manila: PSA.

[14]Philippines Statistics Authority, 2015. Official poverty statistic of the Philippines Manila: PSA.

[15]Philippine Daily Inquirer International Transhipment Port, Ecozones Eyed in Tawi-Tawi. July 2, 2017. Retrieved from http://business.inquirer.net/.

[16]RamliDollahdan Ahmad MosfiMohamad, 2007. PerdaganganTukarBarang Malaysia-Indonesia: PotensidanCabaran. Jati, Vol. 12. December.

[17]Schoofs, S., 2013. Out Of The Shadows: The Real Economy Of The Bangsamoro. Paper presented at the Bangsamoro Workshop Series Files on Nov. 26-27, 2013, Davao City, Mindanao. Retrieved from http://www.fef.org.ph/projects/capacity- building/.

[18]Tsuneishi, T., 2008. Development Of Border Economic Zones In Thailand: Expansion Of Border Trade And Formation Of Border Economic Zones. IDE Discussion Paper, 153. Tokyo: Institute Developing Economy.

[19]Viner, J., 1950. The Custom Union Issue. Carnegie Endowment for International Peace, New York. 